\title{
Which Learning Style Is Most Effective In Learning Chinese As A Second Language
}

\author{
Guanxin Ren, Ruyton Girl's School, Melbourne, Australia
}

\begin{abstract}
Chinese is not only a tonal but also a visual language represented by tens of thousands of characters which are pictographic in nature. This presents a great challenge to learners whose mother tongue is alphabetical-based such as English. To assist English-speaking background learners to learn Chinese as a Second Language (CSL) well, a good understanding of which learning style is most effective in learning CSL is essential. This study attempts to investigate this issue which also has implications for the teaching of Languages Other Than English (LOTE). The specific research questions asked are: (1) which sensory learning style (visual versus auditory versus kinaesthetic) is dominant among secondary school girls in learning CSL; (2) which sensory learning style is most effective among this group of learners; (3) which type of learners achieve better test results, girls with single-sensory domination versus combined-sensory domination. The subjects were 67 secondary school girls aged between 14-18 years old from an independent K-12 girls' school in Melbourne, Australia. A 14-item self-designed questionnaire based on Rose (1985) was administered to all the subjects at the beginning of the academic year in 2011 for learning background and styles profiling. Then, the subjects' individual learning styles were compared with their CSL oral and written examinations scores collected in mid-2011. It has been found that visual learning dominates secondary school girls, and girls with auditory learning style have performed better in oral examinations and those with kinaesthetic learning style have performed better in written examinations. Implications for effective teaching of CSL and other LOTEs are discussed. The contribution this study has made to the existing literature is that girls can learn better by showing their natural learning style strengths without making their learning styles congruent with the teaching style as suggested in previous research.
\end{abstract}

Keywords: Language Learning Styles; Learning Chinese as Second Language; Alphabetical-Based Languages; Visual-Based Languages

\section{INTRODUCTION}

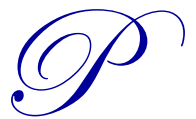

eople learn differently. In the past 40 years, much has been done in the research field of individual learning styles. Numerous numbers of definitions of learning styles have been offered in the literature. Many learning-style models have been created followed by a variety of types of learners being classified. Furthermore, different groups of subjects have been targeted in research into learning styles including: university undergraduates (Garcia-Otero \& Teddie, 1992; Nelson, 1993; Leneham, 1994; McNeal \& Dwyer, 1999; Baykan \& Naçar, 2007), high school students (Fine, 2003; Honigsfield \& Dunn, 2003), primary school pupils (Dunn \& Dunn, 1979; Moustafa, 1999; Dunn \& Griggs, 2000; Dinakar, et at., 2005) and adult learners (Griggs \& Dunn, 1995; Kanske, 2001; Karp, 2003; Smith, 20007). Research claims that male learners are more visual and kinaesthetic-orientate; whereas female learners are more auditory-orientated. Research also claims that the traditional schooling favours visual learners, but not auditory learners (Smith; 1964; Dunn \& Griggs, 1998; and Church, 2004). It has been held by many researchers that matching individuals' learning styles with the teaching style can help learners do better academically (Barbe \& Swassing, 1979; Carbo, 1983; Quinn, 1993; Ford \& Chen, 2001; Mangino \& Griggs, 2003; Lovelace, 2005 to name just a few). Throughout the learning-style literature, there is no mention of any research concerning the learning styles of secondary school girls in learning CSL. The current study intends to bridge this gap by posing the following research questions: 
1. which sensory learning style (visual versus auditory versus kinaesthetic) dominates secondary school girls in learning CSL;

2. which sensory learning style is most effective among this group of learners;

3. which type of learners can achieve better test results in CSL, girls with single learning style versus girls with combined learning styles.

To help seek the answers to the above research questions, this study has posed the following hypotheses:

1. Based on the claim from previous research that female learners are more auditory-orientated, it is hypothesised that auditory learning style will dominate secondary school girls learning CSL.

2. Since the traditional schooling favours visual learners as suggested in the published literature, it is hypothesised that girls with visual learning style will do better in CSL and those with auditory and kinaesthetic learning styles will underachieve in CSL.

3. Given that Chinese is a highly visual language, e.g., in this study, $47 \%$ of the characters required by VCAA (2011) for CSL learners being pictographic by following Tan's (2008) classification, it is hypothesised that girls with visual learning style will do better in CSL in writing.

4. Based on the claim that making learning styles congruent with the teaching style can help learners achieve better academic results, the inferred hypothesis is that without this intervention, girls cannot achieve better academic results in CSL.

The current study intends to prove if the above-listed hypotheses are acceptable or rejected through a questionnairebased approach to secondary school girls' learning-style profiling and an analysis of the Z-scores of the oral and written examinations attempted by this group of learners.

\section{LITERATURE REVIEW}

\section{What has been said about learning styles?}

The research field of learning styles is massive and messy. Since the 1970s, hundreds and thousands of books, journal articles, research reports, conference proceedings as well as recent online publications have been published to devote to the research into this topic, but conceptualising and classifying learning styles remain to be problematic and confusing. The research seems to come from all directions, across and within many disciplines such as psychology, neuroscience, sociology, business studies, management, and education. Up to date, there are more than 70 learning-style models identified of which 13 are claimed to be the most influential (Coffield, et al., 2004).

There are also numerous definitions of learning styles offered from different perspective in the literature, but many are overlapping in nature. In addition, over 50 different types of learners have been categorised under the banner of learning styles including: Field-Dependent/Independent (Witkin, 1973; Garger \& Guild, 1984), Concrete Sequential/Random versus Abstract Sequential/Random (Gregoric, 1979), Initiators, Reasoners, Analysts, and Implementers (Honey \& Mumfard, 2000; Jackson, 2002), Left-Brain versus Right-Brain (Sperry, 1973; Springer \& Deutsch, 1989), Visual, Auditory, and Kinaesthetic (Rose, 1985), Imaginative, Analytic, Common Sense, and Dynamic (McCarthy, 1990), Meaning-, Application-, Reproduction-Directed, and Undirected (Vermunt, 1996), Legislative, Conservative, Executive, and Judicial (Sternberg, 1999), Divergers, Assimilators, Convergers, and Accommodators (Kolb, 2000; Backer \& Yelich, 2005), Environmental-, Emotional-, Sociological-, Physiological-, and Psychological-Stimuli (Dunn \& Griggs, 2003) and so on.

Added to this confusion is when some researchers mix the concept of learning styles with cognitive styles (Keefe, 1979; Willings, 1988; Richards \& Lockhart 1994; Wang, 2007) or thinking styles (Sternberg, 1999) or personality styles (Myers \& McCaulley, 1985) and others separate it from cognitive styles (Desmedt, 2004) or strategies (Entwistle, et al., 1979: Riding \& Cheema, 1991). There are also researchers who do not even believe that learning styles exist. For instance, Riener and Willingham (2010) argue that there is no need to convince people that the learning-styles theory exists, because we all know that students differ in learning anyway. In supporting this view, they continue to say that there are many factors which affect learning, e.g., talent, ability, intelligence, interest in or attention on a learning subject, background knowledge, or specific learning disabilities, and so on. All these 
dimensions vary from person to person, therefore, simply to put the emphasis on learning styles only will be at the expense of these other important dimensions.

Despite the confusion clouded in the literature concerning learning styles, three broad approaches to learning styles seem to have emerged. The first approach is cognitive-based, which intends to define learning styles from the point of view of individuals' behavioural patterns in perceiving and receiving information (Keefe, 1979; Cornett, 1983; Kolb, 1984; Dunn \& Griggs, 1998; Church, 2004; Ellis, 2005; Backer \& Yelich, 2005). The second approach is theoretical-based, which attempts to establish theoretical models to explain how different learning styles should be rationally structured and interconnected. The most frequently-cited theoretical models in order of chronology in the literature include: Learning Styles Inventory (LSI) established by Dunn and Dunn (1975), Learning Styles Inventory (LSI) created by Kolb (1976), Learning Styles Questionnaire (LSQ) promoted by Honey and Mumford (1982), The 4MAT System designed by McCarthy (1990), Inventory of Learning Styles (ILS) suggested by Vermunt (1996), and Learning Styles Profiler (LSP) proposed by Jackson (2002), to list just a few. The third approach is sensory-based, which aims to explain how individuals learn by using their bodily senses, e.g., visual, auditory, kinaesthetic, and tactile (Barbe \& Swassing, 1979; Rose, 1985; Markova, 1996; Moustafa, 1999; Dunn, 2000; Baykan \& Naçar, 2007; Chandler, 2011). As kinaesthetic learning is concerned with physical involvement in a learning situation and tactile with hands-on experiment (Dunn, 1983), of which the two are similar in nature, the current study is to combine the two and label kinaesthetic to represent the sense of touch.

Review of the literature shows that the root of the sensory approach can be traced back to NLP (Neuro Linguistic Programming), which is a neurological filtering system discovered by Bandler \& Grinder in the late 1970s. This system examines how gurus process mental information internally to achieve perfection externally in their chosen field. Following the examination, modelling is enabled to allow others to achieve the same level of success like gurus. In a sense, it is a psychological 'cloning' for repeated success by different people. Such modelling has been successful since its creation as the same behavioural outcomes of the person modelled can be achieved systematically (Bandler \& Grinder, 1979).

A key element of NLP is that people sense the world around them through five modalities: visual, auditory, kinaesthetic, olfactory, and gustatory which correspond to five senses: sight, hearing, touch, smell and taste. When communicating with the outside world, people use all five senses all the time, but the question is which portion of the complex internal process people are aware of at a point in time. According to Bandler \& Grinder (1979), all channels are processing information all the time, but only part of that will be in consciousness. Therefore, as revealed in NLP, out of the five senses, visual, auditory and kinaesthetic sensory modalities seem to dominate mental processing. Later on, these three modalities have formed a basis for the development of the most recognised learning styles that people refer to today, viz. visual, auditory and kinaesthetic.

How many senses do human beings really have? The published literature provides us with no conclusive consensus. The classical five are: sight, taste, smell, touch and hearing (Bandler \& Grinder, 1979; Ellerton, 2003), but Lesch (2008) argues that there are seven adding vestibular and proprioception. The former is about balance, the latter motion. Anissimov (2011) holds that humans have at least nine senses including: sight, taste, smell, touch, hearing, equilibrioception, proprioception, thermoception, and nociception. In Anissimov's (2011) classification, equilibrioception is referred to balance and proprioception motion. Thermoception is the sense of temperature and nociception allows people to experience pain. The current study supports the view of the founders of NLP and argues that sight, hearing and touch are the most essential primary senses in language learning; therefore, visual, auditory and kinaesthetic learning are the most relevant styles to consider.

\section{What has been done in the research field of learning styles?}

In the past 40 years or so, a great number of learning-style researchers have made a strong claim that students can achieve better academic results when their preferred learning styles are congruent with the teaching style (Barbe \& Swassing, 1979; Trautman, 1979; Carbo, 1983; Kolb, 1984; Clark-Thayer, 1987; Dunn, et al., 1990; Quinn, 1993; Sudzina, 1993; Lenehan, et al., 1994; McCarthy, 1994; Wooldridge, 1995; Dunn \& Dunn, 1998; Guild \& Garger, 1998; Miller, 1998; Dwyer, 1998; Dunn \& DeBello, 1999; Dunn, 1982; 2000; Ford \& Chen, 2001; Mangino \& Griggs, 2003; Dunn, 2003; Simpson \& Yunfel, 2004; Lovelace, 2005). Many researchers have 
attempted to prove this point through empirical studies focusing on different groups of learners, e.g., undergraduates (Garcia-Otero \& Teddie, 1992; Nelson, 1993; Leneham, 1994), elementary school students (Moustafa, 1999), remedial-course participants (Rochford, 2004), students attempting tests (O'Brien, 1999) or completing homework (Dunn \& Geiser, 1998) as well as airline pilots (Kanske, 2001; Karp, 2003) and Hispanic-Americans (Griggs \& Dunn, 1995) and so on.

However, there are researchers who have made counter claims against this so-called 'matching hypothesis' (Coffield, et al., 2004). In the late 1980s, Kavale and Forness (1987) argued that there was no evidence to suggest that matching learning and teaching styles could improve students' learning. In the 2000s, there are still researchers who strongly uphold this view. Riener and Willingham (2010) claim that there is no evidence to support 'matching hypothesis'. Coffield, et al (2004) argue that matching learning and teaching styles is unrealistic, because it is impossible for teachers, tutors and instructors to respond to the needs of a great variety of learners with so many different learning styles identified to date. Spoon and Schell (1998) conducted an empirical study into 'matching hypothesis' in education and training. They divided their subjects into Congruent Group where there was a match between learning styles and the instructional style and Incongruent Group where there was no match. The results showed that no significant difference in test scores was found between the two groups. McNeal and Dwyer (1999) administered Kolb's (1999) Learning Styles Inventory (LSI) to determine the learning styles of 154 American nursing students and found no evidence to support the claim that matching students' learning styles with the instructor's teaching style could enhance students' learning.

Many learning-style researchers attempt to determine which learning style is dominant in learning. Dunn and Dunn (1979) surveyed the learning styles of the school-aged children and found that approximately $40 \%$ were visual learners, $30 \%$ auditory and $30 \%$ bi-sensory (e.g., kinaesthetic/tactile or visual/tactile combined). In a separate study, Dunn and Griggs (2000) researched the learning styles of the elementary school children and found that approximately $40 \%$ were visual learners, $12 \%$ auditory, and 48\% kinaesthetic. Karp (2003) used Dunn's (2000) model to analyse the learning styles of over 300 pilots in America and found that $45 \%$ of the pilots were kinaesthetic learners. Ren (2004) researched into the benefits of Mind Map (Buzan, 1993) for senior secondary school boys of CSL undertaking U3-4 and found that $44 \%$ of the boys were visual learners, $27 \%$ auditory, $23 \%$ bi-sensory and only $6 \%$ kinaesthetic. Smith (2007) claimed that $60 \%$ of the general population in America were visual learners; $30 \%$ auditory; and 10\% kinaesthetic. Dinakar, et al (2005) studied the learning styles of the caregivers of asthmatic children and found that $61 \%$ were kinaesthetic learners, and $27 \%$ were read-and-write learners, and the remaining were visual or auditory learners. According to Fleming and Miles (1992), read-write learners prefer printed texts, lecture notes or handouts as a means of information intake; therefore, they should belong to the category of visual learners. Baykan and Naçar (2007) surveyed 155 first year medical students in Turkey and found that only 3.2\% were visual learners, $1.9 \%$ were read-write learners, $7.7 \%$ auditory, $23.3 \%$ kinaesthetic, and the remaining $63.9 \%$ were multisensory learners. All these studies seem to indicate that domination of a particular learning style depends on which section of learners one surveys and domination varies from one group to another. So far, there is no consensus about which learning style is dominant among what type of learners.

There are also researchers who attempt to find out if gender plays a role in learning styles. In three separate studies, Smith (1964), Dunn and Griggs (1998), and Church (2004) have confirmed that gender does play a role in influencing how individuals learn. They find that males are more visual-, and kinaesthetic-orientated in learning and females are more auditory-orientated. Whether this holds true among secondary school girls in learning CSL is unknown.

Learning styles are not without any problems. Haggart (2003) reports that visual learners have trouble working in a noisy setting, auditory learners have trouble reading quietly, and kinaesthetic learners have trouble sitting still while reading. Both auditory and kinaesthetic learners also have trouble to picture an event or setting in a book (Barbe \& Swassing, 1979; Haggart, 2002; Hutton, 2006). Younger kinaesthetic learners often have trouble remembering verbal instructions (Carbo, Dunn \& Dunn, 1986). Fliess (2006) and Haggart (2003) claims that kinaesthetic learners can easily get in trouble in class, because they are movement-orientated and easily-distracted; therefore, they are often mislabelled as having ADHD (Attention Deficit Hyperactivity Disorder). 
It is held by some learning-style researchers that the traditional educational system favours visual learners, because the majority of educators have visual preferences (Haggart, 2003). In addition, tests are usually in a written format, which is easier for students with a visual learning style; therefore, visual learners win the "game of school" (Wayman, 2003); whereas kinaesthetic and auditory learners are more likely to underachieve in school, because they have limited opportunities to use their style strengths in the classroom (Guild \& Garger, 1998). Rochford (2003) claims that less than a third of college students are kinaesthetic learners and they cannot achieve academic successes due to the fact that they are taught in a traditional teaching environment by being forced to sit and listen passively in lecture theatres.

Throughout the literature reviewed, there is no mention about which type of learning style is dominant and most effective among secondary school girls learning CSL. The current study is to address this issue. The significance of this study is that it will bridge the gap in the literature concerning learning styles and provide educators and language teachers with some insight into how to teach CSL effectively, which will also have some implications for the teaching of other LOTEs.

\section{METHODOLOGY}

\section{Subjects}

The subjects of this study were 67 secondary school girls aged between 14-18 years old from an independent girls' school in Melbourne, Australia. Among them, 90\% were born in Australia and 10\% in other countries including the United Kingdom, New Zealand, South Africa and Indonesia. Since none of the subjects either resided in China, Taiwan, Hong Kong or Macao for over 12 months, and none received any formal education in Chinese in a school in China,, Taiwan, Hong Kong or Macao, they are all qualified to be CSL learners by following the selection criteria specified in the Study Design for CSL by Victorian Curriculum and Assessment Authority (VCAA, 2011). As far as the length of learning CSL in Australia is concerned, 63\% of the subjects have studied CSL for 2-5 years before commencing this study and 37\% for more than 5-8 years. The languages the subjects speak at home vary. English is the dominant language spoken at home taking up 66\%. Apart from English, $28 \%$ of the subjects speak another language or dialect at home including: Greek, Vietnamese, Thai and Cantonese. $6 \%$ of the subjects do not speak English at home, but only one dialect such as Indonesian or Cantonese.

\section{Instrument}

The instrument used in this study was a 14-item self-designed questionnaire based on Rose (1985). It was administered to the subjects at the beginning of the academic year in 2011 to measure their primary sensory learning styles. In late-July, 2011, a report format was used to collect the subjects' mid-year oral and written examinations scores. Then, the two types of variables were compared to find out which sensory learning styles had the highest percentage of learners who achieved an A+ or A grade. These grades were determined by following the following scaling:

\section{Assessment Grades}

\begin{tabular}{|c|c|c|c|c|c|c|c|c|c|c|}
\hline $\mathbf{A}+$ & $\mathbf{A}$ & $\mathbf{B +}$ & $\mathbf{B}$ & $\mathbf{C +}$ & $\mathbf{C}$ & $\mathbf{D +}$ & $\mathbf{D}$ & $\mathbf{E}+$ & $\mathbf{E}$ & $\mathbf{U G}$ \\
\hline $93 \%-$ & $83 \%-$ & $73 \%-$ & $63 \%-$ & $53 \%-$ & $43 \%-$ & $35 \%-$ & $27 \%-$ & $19 \%-$ & $12 \%-$ & $0 \%-$ \\
$100 \%$ & $92 \%$ & $82 \%$ & $72 \%$ & $62 \%$ & $52 \%$ & $42 \%$ & $34 \%$ & $26 \%$ & $18 \%$ & $11 \%$ \\
\hline
\end{tabular}

Source: RGS Diary 2011: xix

\section{Data Collection}

Data concerning the subjects' learning styles were collected via the questionnaire used in this study. The subjects were asked to respond to the multiple-choice questions set in the questionnaire. The responses were anonymous and were collected in class in February, 2011. The response rate was 100\%. Data concerning the subjects' oral and written examination scores were collected via the report by the subjects' Chinese teachers. The response rate was also $100 \%$. Since the oral and written examination scores collected were all raw scores, they were unable to be used for comparison, because they were generated from different examinations across different year 
levels with different means of distribution and standard deviation; therefore, these raw scores had to be standardised in order to make the examination scores comparable. In this study, Z-scores were used for comparison because Zscores can be used to compare scores from different distributions with different means and standard deviations (Price, 2000). Z-Scores are calculated from the following formula:

$\mathrm{z}=(\mathrm{x}-\mu) / \sigma$

In the above, $\mathrm{x}$ is a raw score to be standardized, $\mu$ is the mean of the population, and $\sigma$ is the standard deviation of the population. If the raw score is above the mean, $\mathrm{z}$ is positive. If the raw score is below the mean, $\mathrm{z}$ is negative. In this study, the girls whose examination grades are above $83 \%$ will receive a positive $\mathrm{z}$; whereas those who achieved an examination grade below $83 \%$ will receive a negative $\mathrm{z}$. Hence, the higher the positive $\mathrm{Z}$-score is, the better the girl's performance is in the examination. The format of the oral examination is one-on-one questionand-answer discussion. The format of the written examination consists of the following sections: Character Study, Sentence Structures, Reading \& Responding, and Writing. Both oral and written examinations were designed to measure what the subjects should have mastered after learning CSL for a full semester based on their prescribed textbooks. The results were reported to the parents of the subjects via the school they enrolled in.

\section{Data Presentation and Analysis}

The results of the questionnaires indicate that out of the 67 secondary school girls surveyed, 38 of them are visual learners; 21 auditory; 9 kinaesthetic; and 6 bi-sensory (e.g., visual combined with kinaesthetic, visual combined with auditory, and auditory combined with kinaesthetic). There is no girl who has a multi-sensory learning style. The distribution of the girls' learning styles is summarised in Chart 1 below:

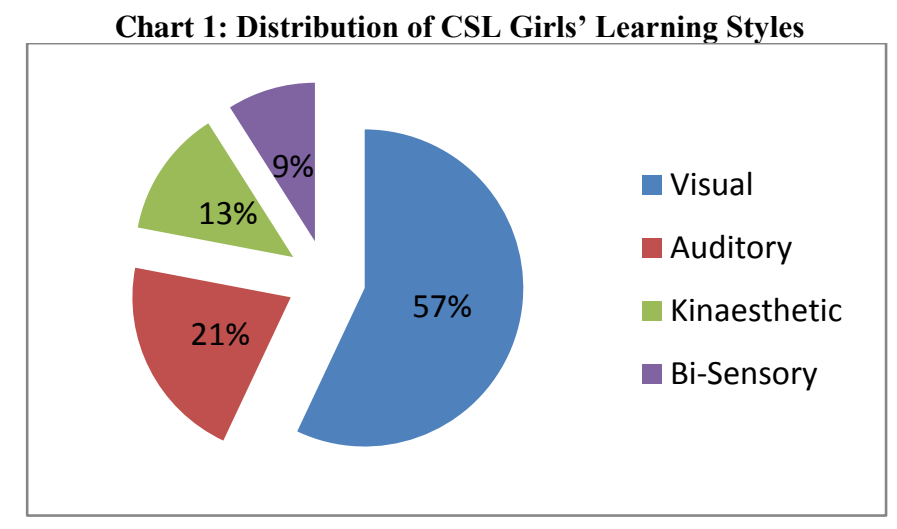

As shown in Chart 1 above, visual learners are the great majority among the secondary school girls learning CSL totalling 57\%. This is followed by auditory learners (21\%) and kinaesthetic learners (13\%). The least dominant group is bi-sensory learners which only take up $9 \%$. Following the claim made in the learning-style literature, visual learners should be the top-performing group in academic achievements. Chart 2 will report if this holds true.

As shown in Chart 2, auditory learners have achieved an average Z-score of +0.00525 . This has placed them on top of the list as far as performance in the oral examination is concerned. Girls with combined learning styles have achieved an average Z-score of +0.00070 ; therefore, they are ranked second. Overall, kinaesthetic learners have performed below the standard with a negative reading of $-0.00001 \mathrm{Z}$-scores in average. Visual learners have ranked the lowest on the list with a negative reading of $-0.31210 \mathrm{Z}$-scores in oral examination.

Chart 3 below will reveal the written test results of the girls with different learning styles: 


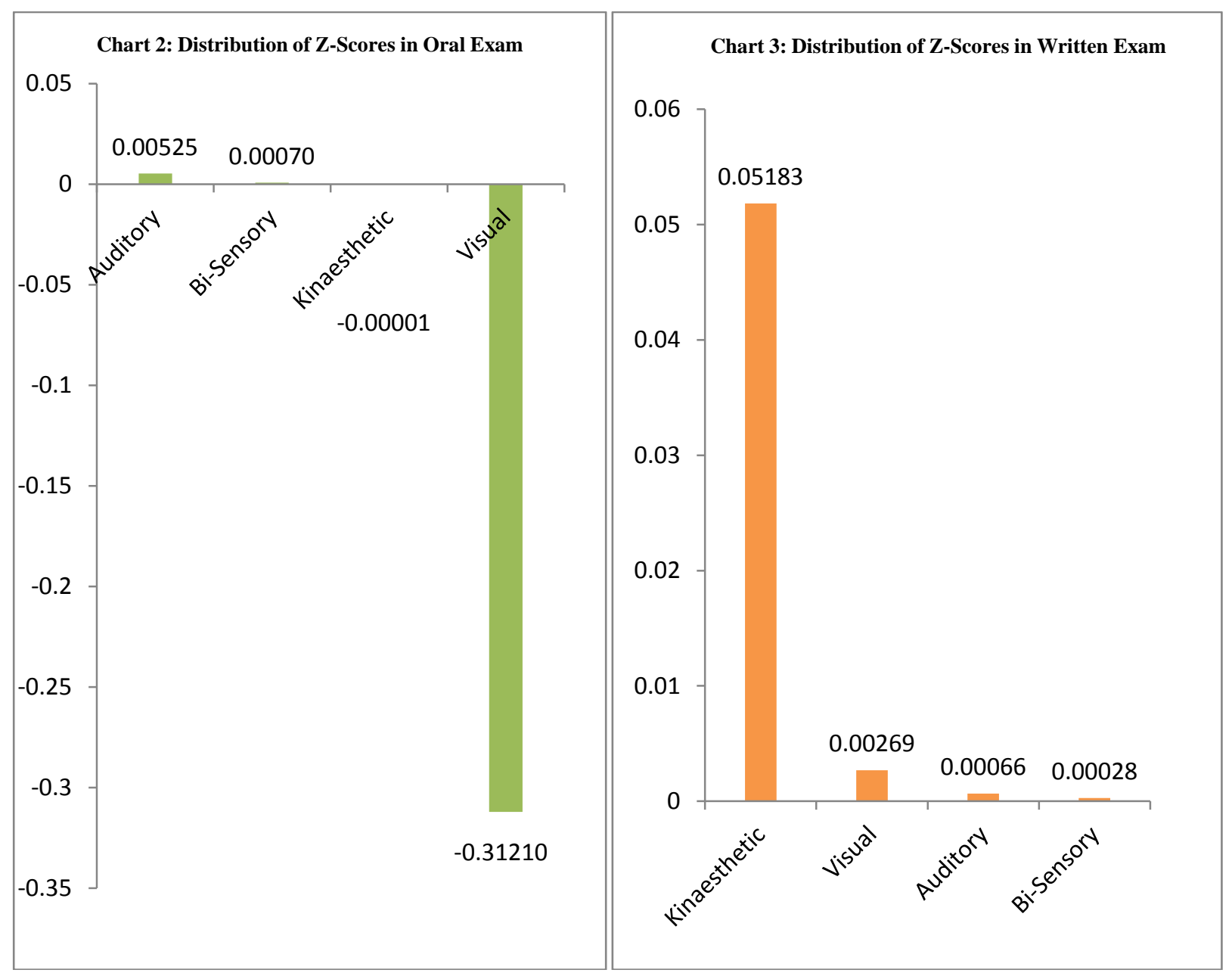

As shown in Chart 3, kinaesthetic learners are the best performing group in CSL with a positive reading of $0.0518 \mathrm{Z}$-scores in average. Visual learners are right behind, having achieved a positive reading of $0.00269 \mathrm{Z}$-scores in average. Auditory learners are ranked third in writing with a positive reading of $0.00066 \mathrm{Z}$-scores in average. The least performing scorers in writing are the girls with combined learning styles. They have only achieved an average of $0.00028 \mathrm{Z}$-scores in the written examination.

\section{FINDINGS}

Based on the data presented in this study, it has been confirmed that visual learners are the great majority (57\%) among the secondary school CSL girls under investigation; therefore, the first hypothesis, which states that auditory learning style dominates secondary school girls studying CSL, is rejected.

The second hypothesis that girls with visual learning style will do better in CSL at school is also rejected inasmuch as the girls with auditory learning style have performed better orally; whereas the girls with kinaesthetic learning style have performed better in writing.

The third hypothesis that visual learner will learn the highly-visual language of Chinese better is also rejected due to the fact that the girls with visual learning style have never been ranked on top of the list neither in oral nor in written examinations. The claim that visual learners win the "game of school" (Wayman, 2003) may need to be reconsidered since it is not true among the secondary school girls in learning CSL. 
The fourth hypothesis, which states that learners cannot learn effectively without making their learning styles congruent with the teaching style, is rejected as well, because this study shows that without any intervention, girls with auditory and kinaesthetic learning styles can still achieve better academic results in CSL. They simply have to show their learning style strengths in a natural way.

Based on the findings stated above, the following have clearly answered the research questions raised at the beginning of this study:

- Visual learning style dominates the secondary school CSL girls instead of auditory learning style as suggested by previous research.

- $\quad$ Auditory learning style is most effective in oral Chinese; whereas kinaesthetic learning style is most effective in written Chinese among the girls studying CSL.

- $\quad$ Girls with single learning style can achieve better test results in CSL than those with combined learning styles.

\section{Implications for Teaching CSL and other LOTEs}

The findings of this study have three key implications for the teaching of CSL and other LOTEs. Firstly, the dominant learning style might not be necessarily the strongest learning style in terms of language performance among a particular group of learners; therefore, language teaching should take into consideration learners' strongest learning style and focus on developing its strengths rather than mixing it with other learning styles to match with the teaching style. Clearly in CSL, the focus should be on auditory and kinaesthetic learning styles; and in other LOTEs, the focus should be on those yet to be identified first and then facilitation can take place in class. Teaching without a targeted approach cannot produce efficiency in learning.

Secondly, success can be copied. Since girls of auditory and kinaesthetic learning styles have been so successful in their learning of CSL, girls of visual learning style should copy auditory and kinaesthetic learners' learning strategies. For CSL teachers, they should focus their teaching on the examination of auditory and kinaesthetic learners' learning behaviours and the analysis of their success in order to repeat the success for visual learners. To be specific, visual and kinaesthetic learners should copy how auditory learners approach their oral tasks in CSL; and visual and auditory learners should copy how kinaesthetic learners approach their written tasks in CSL. For teachers of other LOTEs, the similar strategies should be employed once the strongest learning styles of their own students have been identified.

Thirdly, bodily senses have a direct and close link with the learning of a LOTE including CSL. To learn the target language well, one has to use one's ears to listen and mouth to speak more often. Most importantly, one has to create opportunities to learn by getting involved and using one's hands more often. Chinese has a saying related to learning in general, which goes literally like this: "Reading something a thousand times is no better than writing it down once". This saying puts emphasis on utilising one's kinaesthetic sense and getting involved physically in learning. The findings of this study perhaps remind us of this simple idea again. Therefore, it is imperative for language learners to associate themselves with more learning opportunities by getting involved physically and especially by gaining more hands-on experiences in learning.

\section{AUTHORS INFORMATION}

Dr Guanxin Ren teaches Chinese at Ruyton Girls' School in Melbourne, Australia. He can be contacted at reng@ruyton.vic.edu.au

\section{REFERENCES}

1. Anissimov, M. (2011). How many human senses are there? Retrieved 15 July 2011 from: http://www.wisegeek.com/how-many-human-senses-are-there.htm 
2. Backer, P.R. and Yelich, S. (2005). Comparison of learning styles and student achievement of aviation students. Report for Department of Aviation \& Technology, San Jose State University, San José, USA. Available at: http://www.engr.sjsu.edu/pabacker/presentations/UAA2002learning_styles_aviation_Backer_Yelich.pdf

3. Bandler, R. and Grinder, J. (1979). Frogs into Princes: Neuro Linguistic Programming. Moab, UT: Real People Press.

4. Barbe, W. B. and Swassing, R. H. (1979). Teaching through Modality Strengths: Concepts and Practices. Columbus, Ohio: Zane-Bloser.

5. Baykan, Z. and Naçar, M. (2007). Learning styles of first-year medical students attending Erciyes University in Kayseri, Turkey, Advances in Physiology Education, 31, 158-160.

6. Buzan, T. (1993). The Mind Map Book, London: BBC Books.

7. Carbo, M.L. (1983). Research in reading and learning styles: implications for exceptional children. Exceptional Children, 49(6), 486-493.

8. $\quad$ Carbo, M., Dunn, R. and Dunn, K. (1986). Teaching Students to Read through Their Individual Learning Styles. Englewood Cliffs, NJ: Prentice Hall.

9. $\quad$ Chandler, J. (2011). Sensory learning styles. Retrieved 4 May 2011 from: http://www.ehow.com/about 5449522_vak-learning-style.html

10. Clark-Thayer, S. (1987). The relationship of the knowledge of students perceived learning-style preferences and the study habits and attitudes to achievement of college freshmen in a small urban university (Doctoral Dissertation, Boston University, 1987). Dissertation Abstracts International, 48(04), 872A.

11. Coffield, F., Moseley, D., Hall, E. and Ecclestone, K. (2004). Learning Styles and Pedagogy in Post-16 Learning: A Systematic and Critical Review. London: Learning Skills and Research Centre. Www.LSRC.ac.uk

12. Cornett, C.E. (1983). What You Should Know About Teaching And Learning Styles. Bloomington: Phi Delta Kappa Educational Foundation.

13. Church, S. (2004). Learning styles. Retrieved 8 May 2011 from: http://www.teresadybvig.com/learnsty.htm

14. Desmedt, E. (2004). Research into the theoretical base of learning styles in view of educational applications in a university setting. Unpublished PhD Dissertation. Belgium: Ghent University.

15. Dinakar. C., Adams, C., Brimer, A. and Silva, M.D. (2005). Learning styles of first-year medical students attending Erciyes University in Kayseri, Journal of Asthma, 42(8), 683-687.

16. Dunn, K.J. (1982). Measuring the productivity preferences of adults. In National Association of Secondary Principals (Eds.), Students Learning Styles and Brain Behaviour, (pp. 136-141). Reston, VA: National Association of Secondary Principals.

17. Dunn, R. (1983). Learning styles and its relationship to exceptionality at both ends of the spectrum. Exceptional Children, 49 (6), 496-506.

18. Dunn, R. and Dunn, K. (1979). Learning styles/teaching styles: should they . . can they . . be matched? Educational Leadership, 36, 238-244.

19. Dunn, R. and Dunn, K. (1992). Teaching Elementary Students through their Individual Learning Styles: Practical Approaches for Grades 3-6. Boston, MA: Allyn and Bacon.

20. Dunn, R. (2000). Learning styles: theory, research, and practice. National Forum of Applied Educational Research Journal, 13(1), 3-22.

21. Dunn, R. and DeBello, T.C. (1999). Improved Test Scores, Attitudes, and Behaviours in America's Schools: Supervisor's Success Stories. Westport, CT: Bergin \& Garvey.

22. Dunn, R., Bruno, J., Sklar, R. and Beaudry, J.S. (1990). The effects of matching and mismatching minority developmental college students' hemispheric preferences on mathematics test scores. Journal of Educational Research, 83(5), 283-288.

23. Dunn, R., Deckinger, E. L., Withers, P. and Katzenstein, H. (1990). Should college students be taught how to do homework? The effects of studying marketing through individual perceptual strengths. Illinois School Research and Development Journal. 26(2), 96-113.

24. Dunn R. and Geiser, W (1998). A Heart to Heart versus Tongue in Cheek Approach. Michigan Principal.

25. Dunn, R. and Griggs, S. (1998). Learning Styles and the Nursing Profession. New York: National League for Nursing.

26. Dunn, R. and Griggs, S. (2000). (Eds.). Practical Approach to Using Learning Styles in Higher Education. Westport: Bergin \& Garvey. 
27. Dunn, R. and Griggs, S. (2003). Synthesis of the Dunn and Dunn Learning Styles Model Research: who, what, when, where and so what - the Dunn and Dunn Learning Styles Model and its Theoretical Cornerstone. New York: St John's University.

28. Dunn, R. (2003). The Dunn and Dunn learning-style model and its theoretical cornerstone. In R. Dunn and S. Griggs (2003). Synthesis of the Dunn and Dunn Learning Styles Model Research: who, what, when, where and so what - the Dunn and Dunn Learning Styles Model and its Theoretical Cornerstone. New York: St John's University.

29. Dwyer, K.K. (1008). Communication apprehension and learning style preference: correlations and implications for teaching. Communication Education, 47(2), 137-150.

30. Edwards, B. (1979). Drawing on the Right Side of the Brain. London: Fontana.

31. Ellerton, R. (2003). Modalities and representational systems. Retrieved 21 April 2011 from: http://www.renewal.ca/nlp10.htm

32. Ellis, R. (2005). The Study of Second Language Acquisition. Shanghai: Shanghai Foreign Education Press.

33. Entwistle, N., Hanley, M. and Hounsell, D. (1979). Identifying distinctive approaches to studying. Higher Education, 8, 365-380.

34. Fine, D. (2003). A sense of learning style. Principal Leadership. Reston, VA: NASSP, Special Edition, 5559.

35. Fleming, N. and Mills, C. (1992). Not another inventory, rather a catalyst for reflection. To Improve the Academy, Vol,11, p.137-146. Retrieved 16 August 2010 from http://www.varklearn.com/documents/not another_inventory.pdf

36. Fliess, S.D. (2006). What it means to be a kinaesthetic learner. Retrieved 3 August 2011 from: http://www.education.com/magazine/article/Ed_Keep_Your_Eye_Ball/

37. Ford, N. and Chen, S.Y. (2001). Matching/mismatching revisited: an empirical study of learning and teaching styles. British Journal of Educational Technology, 32(1), 5-22.

38. Haggart, W. (2002). A guide to The Kaleidoscope Profile: Interpreting your styles. Cadiz KY: Performance Learning Systems.

39. Haggart, W. (2003). Discipline and Leaning Styles: An Educator's Guide. Cadiz, KY: Performance Learning Systems.

40. Honey, P. and Mumford, A. (2000). The Learning Styles Helper's Guide. Maidenhead: Peter Honey Publications Ltd.

41. Honigsfield, A. and Dunn, R. (2003). High school males and females learning style similarities and differences in diverse nations. Journal of Educational Research, 96(4), 195-206.

42. Hutton, S. (2006). Helping kinaesthetic learners succeed. Retrieved 26 August 2011 from: http://www.education.com/magazine/article/kinesthetic_learner/

43. Garcia-Otero, M. and Teddlie, C. (1992). The effect of knowledge of learning style on Anxiety and clinical performance of nurse anaesthesiology students. American Association of Nursing Anaesthesiology Journal, 60(3), 257-260.

44. Garger, S. and Guild, P. (1984). Learning styles: the crucial differences. Curriculum Review, 9-12.

45. Gregorc, A.F. (1979). Learning/teaching styles: potent forces behind them. Educational Leadership, 36 , 234-237.

46. Griggs, S. \& Dunn, R. (1995). Hispanic-American students and learning style. Emergency Librarian, 23(2), $1-8$.

47. Guild, P.B. and Garger, S. (1998). Marching to different drummers (2nd Ed.). Alexandria, VA: Association for Supervision \& Curriculum Development.

48. Jackson, C.J. (2002). Manual of the Learning Styles Profiler. Sydney: Cymeon Research.

49. Kanske, C.A. (2001). Learning styles of pilots currently qualified in United States Air Force Aircraft. Journal of Air Transportation World Wide, 6(2), 33-46.

50. Karp, R. (2003). Maximizing Learning and Knowledge Transfer. Tempe, AZ: Author.

51. Kavala, K.A. and Forness, S.A. (1987). Substance over style: assessing the efficacy of modality testing and teaching. Exceptional Children, 54(3), 228-239.

52. Keefe, J.W. (1979). Learning style: an overview. In J. W. Keefe (Ed.), Student Learning Styles: Diagnosing and Prescribing Programs (pp. 1-17). Reston, VA: National Association of Secondary School Principals.

53. Kolb, D.A. (1984). Experiential Learning: Experience as the Source of Learning and Development. Englewood Cliffs, New Jersey: Prentice Hall. 
54. Kolb, D.A. (1999). The Kolb's Learning Style Inventory, Version 3. Boston: Hay Group.

55. Kolb, D.A. (2000). Facilitator's Guide to Learning. Boston: Hay/McBer.

56. Lenehan, M., Dunn, R., Ingham, J., Murray, J. B. and Signer, B. (1994). Effects of learning style intervention on college students' achievement, anxiety, anger, and curiosity. Journal of College Student Development, 35(6), 461-466.

57. Lesch, M. (2008). The 7 senses? New Life Journal Media LLC. Retrieved 1 May 2011 from: http://findarticles.com/p/articles/mi_m0KWZ/is_8_9/ai_n30933547/

58. Lovelace, M.K. (2005). A meta-analysis of experimental research bases on the Dunn and Dunn learningstyle model, 1980-2000. Journal of Educational Research, 98(3),176-183.

59. Mangino, C. and Griggs, S.A. (2003). How learning style responsive approaches increased achievement among college students: Even older learners benefit. In R. Dunn and S. A. Griggs (Eds.), Synthesis of the Dunn and Dunn Learning-Style Model Research: Who, What, When, Where, and So What? Chapter 24, (pp.75-77). NY: St. John's University's Centre for the Study of Learning and Teaching Styles.

60. Markova, D. (1996). The Open Mind: Exploring the 6 Patterns of Natural Intelligence. Berkeley, California: Conari Press.

61. McCarthy, B. (1990). Using the 4MAT System to bring learning styles to schools. Educational Leadership, 48 (2), 31-37.

62. McCarthy, B. (1994). The 4MAT Research Guide. Wauconda, Illinois: About Learning.

63. McNeal, G.H. and Dwyer, F. (1999). Effect of learning style on consistent and inconsistently designed instruction. International Journal of Instructional Media, 26(3), 337-347.

64. Miller, J.A. (1998). Enhancement of achievement and attitudes through individualized learning-style presentations of two allied health courses. Journal of Allied Health, 27, 150-156.

65. Moustafa, B.M. (1999). Multisensory approaches and learning styles theory in the elementary school: summary of reference papers, pp.1-12. ED432 PS027771

66. Myers, I.B. and McCaulley, M.H. (1985). Manual: A Guide to the Development and Use of the MyersBriggs Type Indicator. Palo Alto, CA: Consulting Psychologists Press.

67. Nelson, B., Dunn, R., Griggs, S. A., Primavera, L., Fitzpatrick, M., Bacillious, Z., et al. (1993). Effects of learning-style intervention on college students' retention and achievement. Journal of College Student Development, 34(5), 364-369.

68. O'Brien, L. (1999). It's not how smart you are.... it's how you are smart! Retrieved 27 June 2011 from: http://www.newhorizons.org

69. Price, I. (2000). Research methods and statistics PESS202 lecture and commentary notes. Retrieved 11 September 2011 from:

http://www.une.edu.au/WebStat/unit_materials/c4_descriptive_statistics/z_scores.htm

70. Quinn, P. (1993). Improving communications and teaching: assessing and utilizing learning styles. Family Science Review, 6(3-4), 115-123.

71. Ren, G. (2004). Benefits of Mind Map for students of different learning styles. Languages Victoria, 8(1), 22-26.

72. Richards, J. and Lockhart, C. (1994). Reflective Teaching in Second Language Classrooms. Cambridge: Cambridge University Press.

73. Riding, R. and Cheema, I. (1991). Cognitive styles - an overview and integration. Educational Psychology, 11, 193-216.

74. Riener, C. and Willingham, D. (2010). The myth of learning styles. Retrieved 4 May 2011 from: http://www.changemag.org/Archives/Back\%20Issues/September-October\%202010/the-myth-of-learningfull.html

75. Rochford, R.A. (2003). Assessing learning styles to improve the quality of performance of students in developmental writing programs at an urban community college. Community College Journal of Research and Practice, 27(8), 665-677.

76. Rochford, R.A. (2004).Improving academic performance and retention among remedial students. Community College Enterprise, 10(2), 23-36.

77. Rose, C. (1985). Accelerated Learning. Bucks: Topaz Publishing Ltd.

78. Simpson, C. and Yunfel, D. (2004). Effects of learning styles and class participation on students' enjoyment level in distributed learning environments, Journal of Education for Library \& Information Science, 45(2), 123-136. 
79. Smith, C. (2007). Sensory learning styles. Retrieved April 12, 2011 from: http://www.grapplearts.com/Learning-Styles-in-Grappling.htm

80. Smith, I.M. (1964). Spatial ability. San Diego, CA: Knapp.

81. Sperry, R. (1973). Lateral specialisation of cerebral function in the surgically separated hemisphere. In F.J. McGulgan, and R.A. Schoonover (Eds.) The Psychophysiology of Thinking (pp.209-229), New York: Academic Press.

82. Spoon, J.C. and Schell, J.W. (1998). Aligning student learning styles with instructor teaching styles. Journal of Industrial Teacher Education, 35(2), 41-56.

83. Sudzina, M. (1993). An investigation of the relationship between the reading styles ofsecond-graders and their achievement in three basal reader programs. Dayton, OH: The University of Dayton, Department of Teacher Education. (ERIC ED 353 569)

84. Springer, S.P. and Deutsch, G. (1989). Left-Brain Right-Brain. New York: Freeman.

85. Sternberg, R.J. (1999). Thinking Styles. Cambridge: Cambridge University Press.

86. Tan, H.P. (2008). What's in a Chinese Character. Beijing: New World Press.

87. Trautman, P. (1979). An investigation of the relationship between selected instructional techniques and identified cognitive style. Dissertation Abstracts International: Section A. Humanities and Social Sciences, 40(03).

88. VCAA. (2011). Updated Character List for VCE Chinese Second Language/Second Language Advanced. Melbourne: Victorian Curriculum and Assessment Authority. Retrieved 12 September 2011 from: http://www.vcaa.vic.edu.au/vcaa/correspondence/notices/2011/attachment/notice13VCECharacterListimplementation.pdf

89. VCAA. (2011). Study Design for Chinese Second Language/Second Language Advanced. Melbourne: Victorian Curriculum and Assessment Authority. Retrieved 12 September 2011 from: http://www.vcaa.vic.edu.au/vce/studies/lote/chinese2nd/chin2ndindex.html

90. Vermunt, J.D. (1996). Metacognitive, cognitive and affective aspects of learning styles and strategies: a phenomenographic analysis. Higher Education, 31, 25-50.

91. Wang, L. (2007). Variation in learning styles in a group of Chinese English as a foreign language learners. International Education Journal, 8 (2), 408-417.

92. Wayman, P. (2003). Amazing grades! Tune-in to your child's personal learning style \& create higher grades in just 14 days. Retrieved 26 August 2011 from: http://www.howtolearn.com/instantamazinggrades.html

93. Willings, K. (1988). Learning Styles in Adult Migrant Education. Adelaide: National Curriculum Research Council.

94. Witkin, D.B. (1973). The role of cognitive style in academic performance and in teacher-student relations. Research Bulletin, Educational Testing Service, Princeton, N.J., 73-101.

95. Wooldridge, B. (1995). Increasing the effectiveness of university/college instruction: integrating the results of learning style research into course design and delivery. In R. R. Sims \& S. J. Sims (Eds.) The Importance of Learning Styles: Understanding the Implications for Learning, Course Design, and Education (pp. 49-68). Westport, CT: Greenwood Press. 